\title{
Cardiac sarcoidosis: Case presentation and Review of the literature
}

\author{
NATALIA CHAMORRO-PAREJA ${ }^{1}$, JULIAN A. MARIN-ACEVEDO ${ }^{2}$, RĂZVAN M. CHIRILĂ ${ }^{2}$ \\ ${ }^{1}$ Division of Pulmonary, Allergy and Sleep Medicine, Mayo Clinic, 4500 San Pablo, Rd, Jacksonville, FL 32224, USA \\ ${ }^{2}$ Division of General Internal Medicine, Mayo Clinic, 4500 San Pablo, Rd, Jacksonville, FL 32224, USA
}

\begin{abstract}
Cardiac sarcoidosis usually occurs in the context of systemic disease; however, isolated cardiac involvement can occur in up to $25 \%$ of cases and tends to be clinically silent. When symptoms are present, they are often nonspecific and occasionally fatal, representing a diagnostic challenge. A high index of clinical suspicion and the integration of appropriate imaging, laboratory, and pathologic findings is always required. Treatment aims to control the systemic inflammatory condition while preventing further cardiac damage. However, even with adequate diagnosis and treatment strategies, prognosis remains poor. We describe the case of a patient who presented with cardiac symptoms, whose initial examination was unrevealing. Diagnosis was made retrospectively based on later systemic manifestations that revealed characteristic sarcoidosis findings.
\end{abstract}

Keywords: AV block; cardiac sarcoidosis; heart failure; implantable cardioverter-defibrillator; ventricular tachycardia.

\section{INTRODUCTION}

Sarcoidosis is a multiorgan inflammatory disease of unknown etiology characterized by the formation of immune, noncaseating granulomas. Global prevalence is estimated around 4.7 to 64 cases per 100,000, with an annual incidence of approximately 10.9 cases per 100,000 in the United States $[1,2]$. The highest rates have been reported among northern Europeans and African-Americans. In this latter group, incidence reaches 35.5 cases per 100,000 $[1,2]$. Although it more frequently involves the lungs and lymphatic nodes, up to $30 \%$ of patients present with extrapulmonary manifestations [3]. The most common sites of extrapulmonary disease include the skin, eyes, reticuloendothelial system, exocrine glands, heart, kidney, and central nervous system [1]. Cardiac sarcoidosis (CS) tends to be clinically silent or present with nonspecific symptoms. Additionally, some tests, such as angiotensin converting enzyme levels, echocardiogram, and endomyocardial biopsy (EMB), lack sensitivity or specificity. Given that the presence of $\mathrm{CS}$ is associated with high morbidity and mortality rates, and that diagnosis can be difficult and is often missed, a high index of suspicion is required to promptly recognize and treat this condition.

We describe the case of a patient who presented with cardiac symptoms, whose initial examination was negative. Diagnosis was made retrospectively based on later systemic manifestations that revealed characteristic sarcoidosis findings.

\section{CASE PRESENTATION}

A 54-year-old African-American woman with a medical history of hypertension and noncontributory family history presented to the emergency department for syncope. This was preceded by palpitations, diaphoresis, and mild chest discomfort. She denied tongue biting or losing sphincter control, and had a spontaneous recovery to baseline in less than 2 minutes. While in the emergency department, she became obtunded and was found to have a heart rate of 260 beats per minute (electrocardiogram was consistent with ventricular tachycardia [VT]), which required electrical cardioversion and amiodarone infusion. Electrophysiologic studies confirmed an isoproterenol-inducible fast sustainable VT associated with transient 2:1 block, for which she underwent radiofrequency ablation. Despite this, VT episodes recurred, and a single-chamber implantable cardioverter-defibrillator was implanted. A transthoracic echocardiogram showed an asymmetric hypertrophic cardiomyopathy with ground glass appearance without left ventricular outflow tract obstruction and decreased left ventricular ejection fraction (LVEF), suggestive of an underlying infiltrative etiology. Cardiac magnetic resonance imaging revealed the presence of diffuse areas of delayed gadolinium enhancement following a nonischemic pattern (Figure 1). To further clarify the etiology of the infiltrative disease, she underwent urine and serum electrophoresis, which showed no paraproteins; fat-pad biopsy with Congo red stain, 
which ruled out amyloidosis; alpha-galactosidase levels, which returned normal, ruling out Fabry disease; and ferritin level, which was normal, excluding hemochromatosis. Additionally, angiotensin-converting enzyme levels were normal.
EMB was nondiagnostic, with negative amyloid and Prussian blue stains. Her findings were labeled hypertensive cardiomyopathy. She continued to be followed periodically by cardiology without any recurrence of VT episodes.

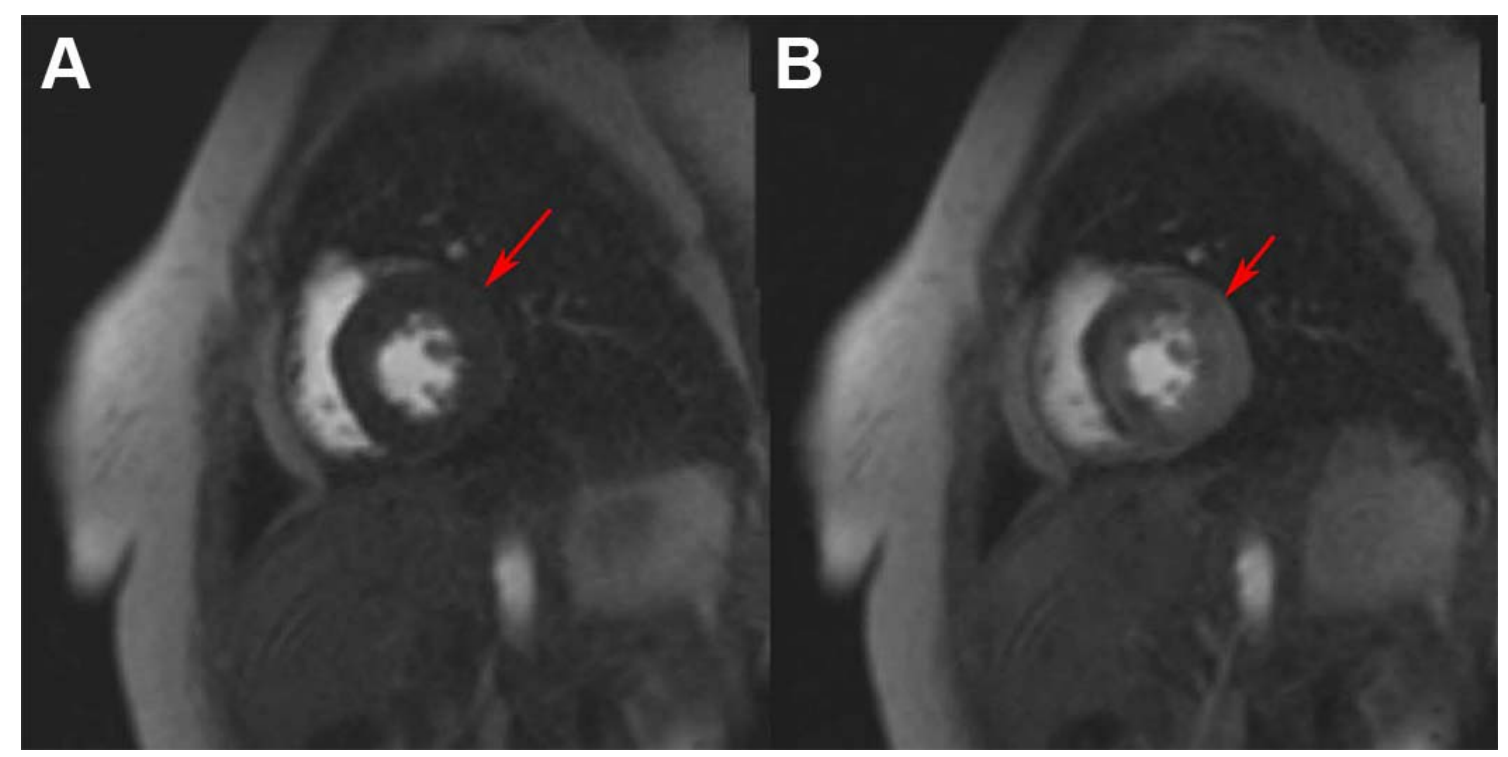

Figure 1. Cardiac Magnetic Resonance. A. Without early enhancement. B. Late gadolinium enhancement on a nonischemic/noncoronary artery distribution (subepicardial and midmyocardial enhancement) (red arrow).

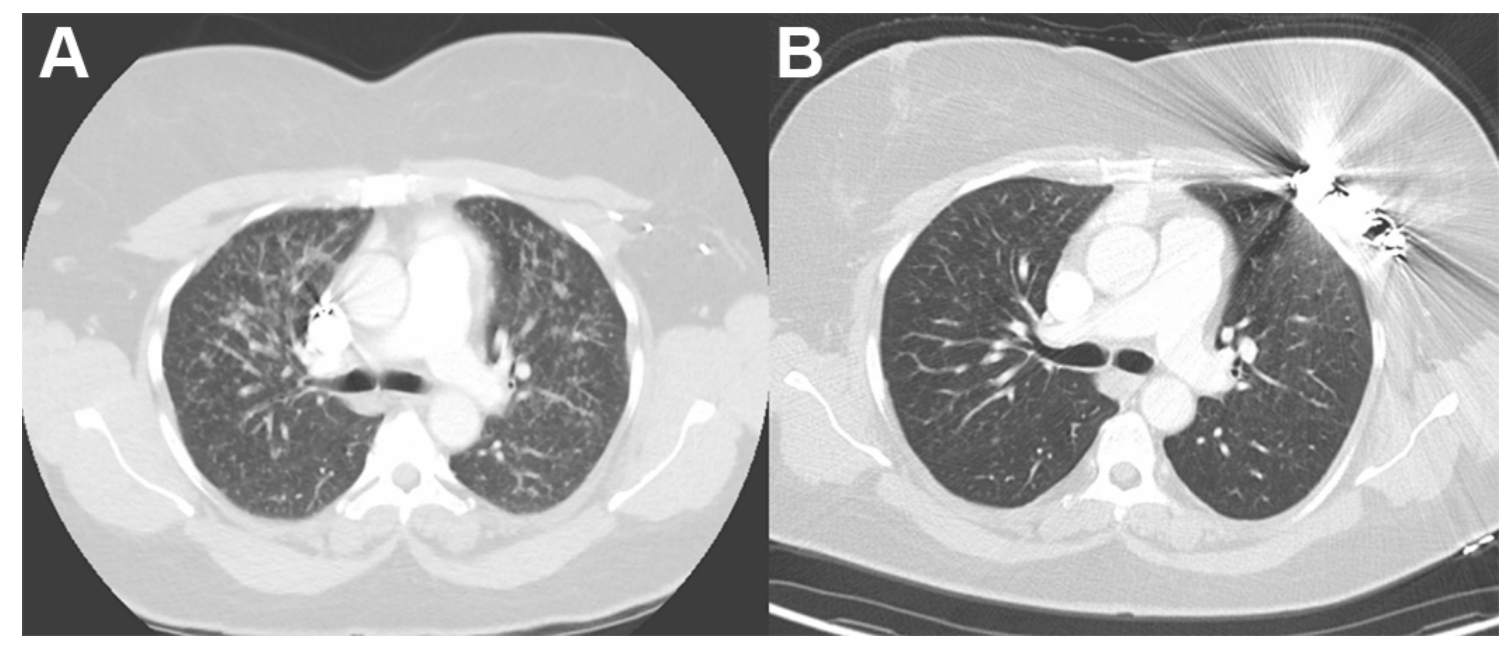

Figure 2. Computed Tomography of the Chest. Diffuse parenchymal pulmonary micronodules seen in initial imaging $(\mathrm{A})$ were notably decreased on subsequent imaging $(\mathrm{B})$.

Three years later, she developed a left parotid mass and was evaluated by otorhinolaryngology. On physical examination, she had a temperature of $36.7^{\circ} \mathrm{C}$, heart rate of 78 beats per minute, respiratory rate of 17 breaths per minute, and blood pressure of $117 / 76 \mathrm{~mm} \mathrm{Hg}$. Her lungs were clear, there was a $1 / 6$ systolic ejection murmur at the left sternal border, and there was no organomegaly on abdominal palpation. Her left parotid region revealed a tender and mobile mass without associated lymphadenopathy. Computed tomography showed a $2.8 \mathrm{~cm}$ by $2.0 \mathrm{~cm}$ by $1.0 \mathrm{~cm}$ mass in the superficial lobe of the left parotid gland. To clarify the etiology of the mass, a parotidectomy was performed. Pathology showed multiple noncaseating epithelioid granulomas with focal necrosis involving the entire gland. Special stains for fungi and acidfast bacilli were negative. Given the concern for sarcoidosis, computed tomography of the chest confirmed the presence of diffuse reticular-nodular 
opacities throughout both lungs. Positron emission tomography revealed hypermetabolic activity areas over the left parotid, bilateral pulmonary parenchyma, and over lymph nodes on the cervical, axillary, and abdominal regions. Considering her history of cardiac disease, a repeat transthoracic echocardiogram confirmed the presence of severe hypokinesis of the basal septum and inferior and anterior walls and further decline on ejection fraction, suggestive of CS. She was started on a high-dose prednisone taper and methotrexate for her systemic disease, and losartan and metoprolol for her CS. Follow-up chest computed tomography performed 3.5 months later showed a remarkable response to therapy (Figure 2).

\section{DISCUSSION}

\section{CLINICAL MANIFESTATIONS}

CS, initially described in 1929 by Bernstein and associates $[4,5]$, usually occurs in the context of systemic sarcoidosis; however, isolated cardiac involvement can occur in up to $25 \%$ of cases [6].

The noncaseating granulomas directly cause edema, inflammation, and subsequent fibrosis, with scarring of the heart tissue that leads to myocardial dysfunction [7]. Although any chamber can be affected, the left ventricle is more often involved [7]. Additionally, the myocardium and its conducting system are particularly vulnerable [5].

Clinical presentation ranges from silent granulomas to palpitations, syncope, and sudden cardiac death depending on the location, extent, and activity of the disease [8]. Given the predilection to affect the conduction system, heart blocks and arrhythmias are common. Atrioventricular (AV) block and VT are the first and second most common clinical presentations, respectively; however, any block or arrhythmia may occur [9, 10]. AV dysfunction occurs more often in younger patients and can range from first-degree block (PR prolongation) to complete AV block [11, 12]. Arrhythmias can be supraventricular or ventricular. Supraventricular arrhythmias include paroxysmal atrial tachycardia, atrial ectopy, atrial flutter, and atrial fibrillation [13]. Ventricular arrhythmias occur in $30 \%$ of cases and comprise sustained and nonsustained VT and ventricular premature beats [9]. Of note, patients with AV blocks or history of VT have an elevated risk for sudden cardiac death, and the latter accounts for $25 \%$ of deaths in CS [14].
Heart failure (HF) occurs less often than arrhythmias, but represents the cause of death in up to $25 \%$ of patients [15]. In fact, the most important predictor of mortality is a depressed LVEF [7]. HF is often secondary to either dilated cardiomyopathy (with reduced LVEF) or restrictive cardiomyopathy (with preserved LVEF) [16]. Right ventricular dysfunction without pulmonary disease tends to affect older patients and usually associates concomitant left-sided HF with preserved ejection fraction [17].

\section{DIAGNOSIS}

Patients with proven systemic sarcoidosis should be evaluated for cardiac involvement given its high prevalence. However, since CS can occur in isolation and present with nonspecific signs and symptoms, a high index of clinical suspicion and integration of appropriate imaging, laboratory, and pathologic findings is always required.

Physical examination findings in isolated CS may reveal a systolic murmur consistent with mitral regurgitation as a consequence of cardiac chamber dilation with or without papillary muscle dysfunction [18].

Angiotensin-converting enzyme levels may be elevated in $60 \%$ of patients with systemic sarcoidosis [19]. This test lacks sensitivity and specificity for the diagnosis of CS, and a negative result does not rule out the presence of the disease.

Electrocardiograms are usually abnormal in patients with CS. Findings comprise different degrees of conduction block and QRS complex fragmentation [20]. Conduction block defects include bundle branch blocks, fascicular blocks, and different grades of AV blocks. QRS complex fragmentation, defined as the presence of an additional $\mathrm{R}$ wave, notching in the nadir of the $\mathrm{S}$ wave, or the presence of more than $1 \mathrm{R}$ wave in 2 anatomically contiguous leads [21], has a high sensitivity and specificity for CS [22]. Other electrocardiogram findings may include supraventricular or ventricular arrhythmias and nonspecific ST T wave changes [20].

Chest radiography may reveal nonspecific findings suggestive of $\mathrm{HF}$, including cardiomegaly, Kerley B lines, and pleural effusions. Chest radiography can also reveal bilateral hilar adenopathy and other findings consistent with pulmonary sarcoidosis. Chest computed tomography is more sensitive and specific than chest radiography in evaluating sarcoidosis [8], especially in detecting mediastinal lymphadenopathy [23]. 
Echocardiography can be normal in clinically silent CS, but it is usually abnormal in patients with clinically manifest disease [8]. Findings may include regional or septal myocardial wall thickening that can mimic hypertrophic cardiomyopathy, interventricular basal septal thinning, ventricular aneurysms, and ventricular global or regional dysfunction, including dyskinesia or hypokinesia [8, 24].

Cardiac magnetic resonance imaging is a valuable aid in the diagnosis of CS due to its high sensitivity and specificity $[15,25]$. Besides the presence of regional wall motion abnormalities and segmental wall thickening or thinning, findings can include localized gadolinium enhancement, which is typically patchy and multifocal, representing a combination of noncaseating granulomas and associated inflammation [24, 26]. These findings usually follow a noncoronary artery distribution pattern and are commonly seen in the septum and lateral wall of the mid-myocardium and epicardium $[8,24]$.

Similarly, positron emission tomography is an accurate diagnostic tool for CS. 18F-fluorodeoxyglucose accumulates in inflammatory cells with high metabolic rate, and its uptake is increased in CS [27]. Although no pathognomonic finding has been described in this imaging modality, its correlation with disease activity suggests a potential role in guiding therapy $[7,8,27]$.

Although histologic demonstration of sarcoidosis is required, patients with systemic disease can be diagnosed with CS without direct cardiac sampling. Usually an extracardiac tissue sampling of the lungs or lymph nodes can reveal the presence of noncaseating granulomas [8]. EMB can be considered when a clear etiology of the disease has not been established. EMB sensitivity has been reported as low as $25 \%$ due to the patchy involvement of the myocardium, as in our patient [28]. To increase the sensitivity of EMB, electrophysiologic mapping or image-guided biopsy can be used [29].

Currently, no validated international guidelines for diagnosing CS are available; however, 2 proposed diagnostic criteria may be used: the Japanese Ministry of Health and Welfare guidelines (Box 1) [30] and the Heart Rhythm Society Expert consensus for diagnosis of CS (Box 2) [29]. Unfortunately, both tools lack sensitivity and specificity [7].

Table 1

Japanese Ministry of Health and Welfare Criteria for Diagnosis of Cardiac Sarcoidosis

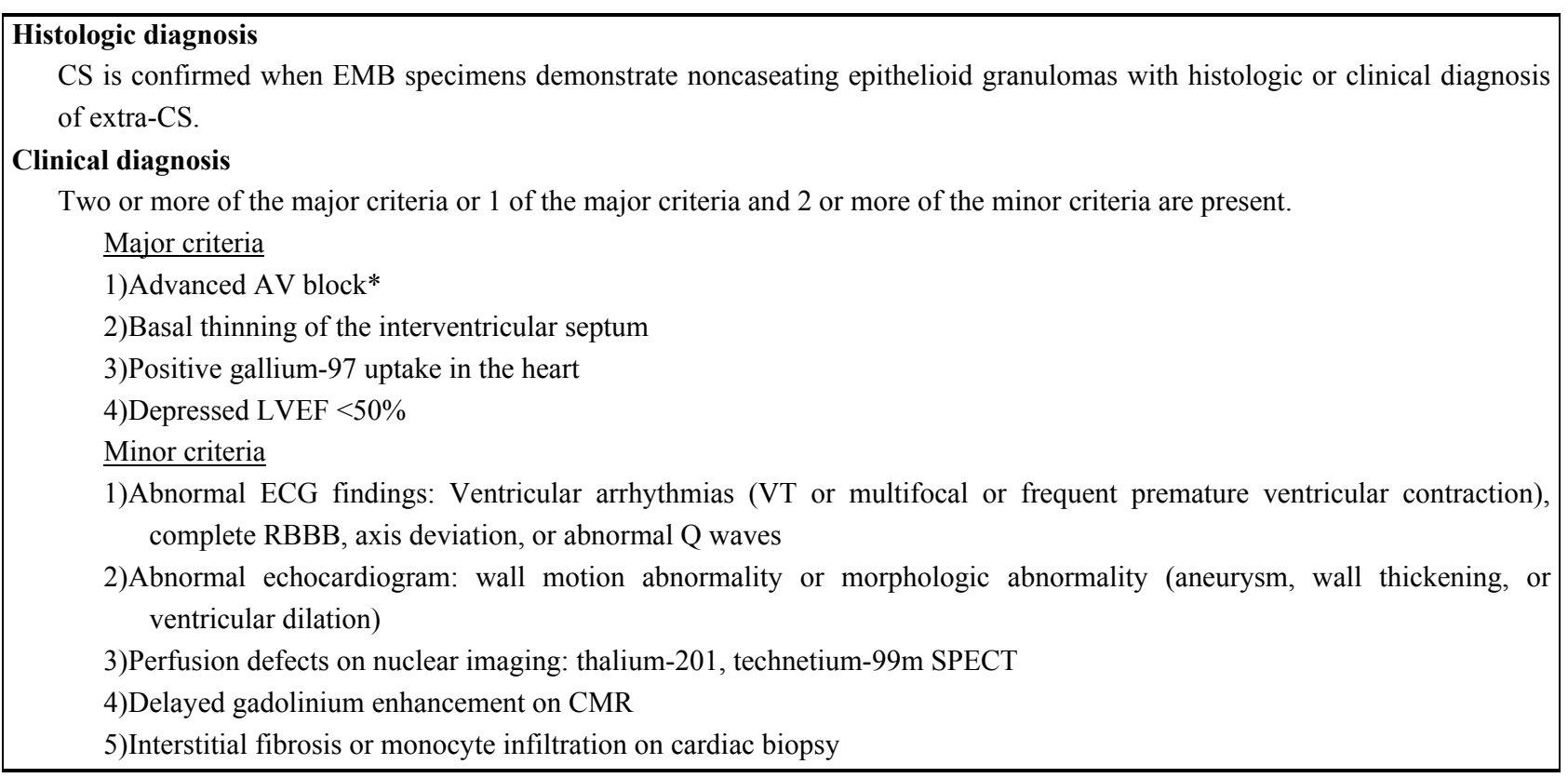

Abbreviations: AV - atrioventricular; CMR - cardiac magnetic resonance; CS - cardiac sarcoidosis; ECG - electrocardiogram; EMB endomyocardial biopsy; LVEF - left ventricular ejection fraction; RBBB - right bundle branch block; SPECT - single-photon emission computed tomography; VT - ventricular tachycardia.

* Advanced AV block: second degree or complete AV block 
Table 2

Heart Rhythm Society Consensus Statement for Diagnosis of Cardiac Sarcoidosis

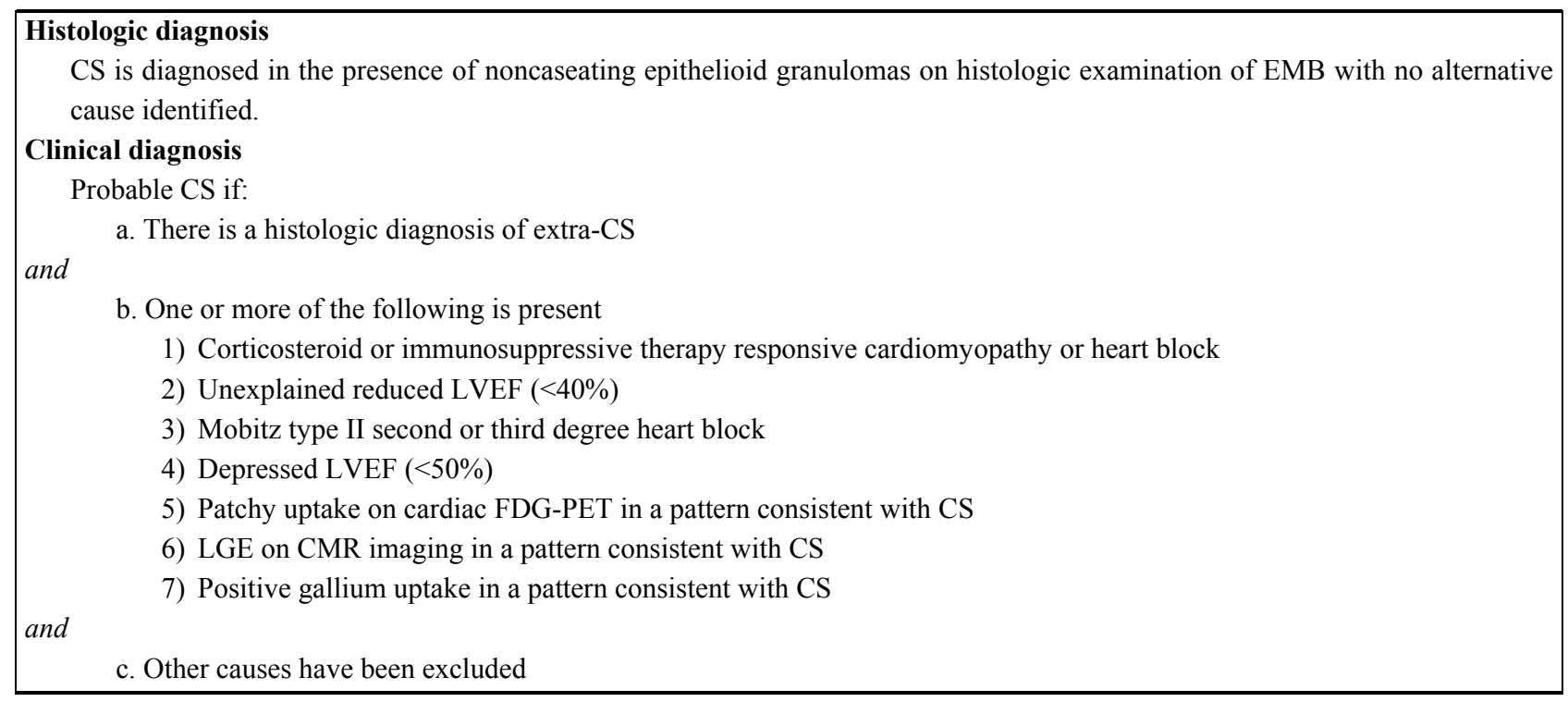

Abbreviations: CMR - cardiac magnetic resonance; CS - cardiac sarcoidosis; EMB - endomyocardial biopsy; FDG-PET - fluorodeoxyglucose positron emission tomography; LGE - localized gadolinium enhancement; LVEF - left ventricular ejection fraction.

\section{TREATMENT}

Management of CS requires a multidisciplinary approach, involving immunosuppressive and cardiacspecific treatment. The goal is to decrease the ongoing inflammatory process and the severity of cardiac dysfunction.

Corticosteroids are the mainstay for treatment of systemic sarcoidosis. Their role in CS is to suppress inflammation, fibrosis, and granuloma formation, thus preventing further deterioration of cardiac function [15]. Although no consensus exists in dosing and length of treatment, a common approach includes the use of prednisone at a dose of 30 to $60 \mathrm{mg}$ /day for 4 weeks, followed by a slow taper to reach a maintenance dose of 5 to $15 \mathrm{mg}$ /day for a period of 6 to 12 months $[15,19,24]$. Patients receiving prednisone at a dose of $20 \mathrm{mg} /$ day or more for at least 1 month should be considered for prophylactic therapy against Pneumocystis jirovecii infection with trimethoprim-sulfamethoxazole [31]. After 6 months of systemic corticosteroid treatment, fluorodeoxyglucose positron emission tomography should be obtained to assess for response. In case of persistent inflammation, corticosteroids should be continued [32]. Glucocorticoid-sparing, such as methotrexate, azathioprine, mycophenolate, and tumor necrosis factor antagonists (e.g. infliximab) can be considered when high doses of prednisone (e.g. $>10 \mathrm{mg}$ /day) or prolonged courses of corticosteroids are required, for those who cannot tolerate corticosteroids, or those who continue to worsen, despite their use $[19,24,33]$. However, given the frequent responsiveness of sarcoidosis to corticosteroids, use of these agents is rare and evidence regarding their use remains scarce $[24,33]$.

Pacemaker implantation is used in patients with an indication for pacing (ie, complete AV block or second-degree AV block). This is performed even if the block transiently reverses, given the progressive nature of the disease [34].

Ventricular arrhythmias may require use of antiarrhythmic agents, catheter ablation, or placement of an implantable cardioverter-defibrillator [29]. No specific antiarrhythmic is preferred over another, and the choice of agent varies by individual. The most commonly used agents are class II and class III antiarrhythmics, particularly amiodarone and sotalol [35]. Amiodarone, however, can sometimes be limiting, given its potential pulmonary toxicity [24]. Class IC antiarrhythmics are often avoided due to coexistent structural heart disease [35]. Catheter ablation is often considered in patients with refractory VTs, despite antiarrhythmics, but its efficacy is highly variable [35]. Implantable cardioverter-defibrillator placement should be considered for patients with sustained ventricular arrhythmias or LVEF of $35 \%$ or less despite optimal medical therapy. Other indications include unexplained syncope with suspected arrhythmic 
etiology and inducible sustained ( $>30$ seconds) monomorphic or polymorphic VT [29]. Patients with HF should receive standard therapy for this condition.

$\mathrm{CS}$ is associated with poor overall prognosis considering its silent course and frequently lethal clinical presentation (e.g. sudden cardiac death). For instance, most cases of CS are diagnosed during autopsy [19].

\section{CONCLUSION}

CS, although usually seen with systemic sarcoidosis, can occasionally present as an isolated disease. Given its nonspecific signs and symptoms and its potentially fatal presentation, diagnosis requires a high index of clinical suspicion and integration of clinical manifestations, imaging, and pathologic data. While the presence of extra-CS may facilitate a histologic diagnosis with the use of extracardiac samples, isolated cardiac involvement may require EMB, despite its low sensitivity. Therefore, use of different cardiac imaging modalities plays an important role in the diagnosis of CS. Treatment of CS depends specifically on the manifestations, and usually combines cardiac-specific treatment with systemic immunosuppression to reduce disease progression and deterioration of cardiac function.

\section{Acknowledgments. None.}

Conflict of interest disclosure: The authors declare that there are not conflicts of interest.

Sarcoidoza cardiacă apare de obicei în contextul bolii sistemice. Totuşi aceasta poate să apară izolat în $25 \%$ din cazuri şi are tendința să fie silențioase clinic. Atunci când simptomele sunt prezente ele sunt de obicei nespecifice şi ocazional fatale, ceea ce reprezintă o provocare pentru diagnostic. Este necesar un index ridicat de suspiciune clinică cu integrarea datelor imagistice, de laborator şi histopatologice. Tratamentul ținteşte către controlul inflamației sistemice prevenind în acelaşi timp degradarea funcției cardiace. Prognosticul rămâne rezervat în ciuda diagnosticului şi a aplicării tratamentului. Prezentăm cazul unei paciente care s-a prezentat cu simptome cardiace la care examinarea inițială nu a fost caracteristică. Diagnosticul a fost pus retrospectiv bazat pe manifestări sistemice care au relevat sarcoidoza.

Correspondence to: Răzvan M. Chirilă, MD, Division of General Internal Medicine,

Mayo Clinic, 4500 San Pablo Road, Jacksonville, FL 32224, USA

Phone 904-953-2824 Fax 904-953-2848)

E-mail: Chirila.Razvan@mayo.edu

\section{REFERENCES}

1. VALEYRE D., PRASSE A., NUNES H., UZUNHAN Y., BRILlET P.Y., MULLER-QUERNHEIM J. Sarcoidosis. Lancet (London, England). 2014; 383(9923):1155-67.

2. IANNUZZI M.C., RYBICKI B.A., TEIRSTEIN A.S. Sarcoidosis. N Engl J Med. 2007;357(21):2153-65.

3. RIZZATO G., TINELLI C. Unusual presentation of sarcoidosis. Respiration. 2005;72(1):3-6.

4. SILVERMAN K.J., HUTCHINS G.M., BULKLEY B.H. Cardiac sarcoid: a clinicopathologic study of 84 unselected patients with systemic sarcoidosis. Circulation. 1978;58(6):1204-11.

5. SHARMA O.P., MAHESHWARI A., THAKER K. Myocardial sarcoidosis. Chest. 1993;103(1):253-8.

6. OKADA D.R., BRAVO P.E., VITA T., AGARWAL V., OSBORNE M.T., TAQUETI V.R., et al. Isolated cardiac sarcoidosis: A focused review of an under-recognized entity. J Nucl Cardiol. 2016.

7. HULTEN E., ASLAM S., OSBORNE M., ABBASI S., BITTENCOURT M.S., BLANKSTEIN R. Cardiac sarcoidosis-state of the art review. Cardiovasc Diagn Ther. 2016;6(1):50-63.

8. BIRNIE D.H., NERY P.B., HA A.C., BEANLANDS R.S. Cardiac Sarcoidosis. J Am Coll Cardiol. 2016;68(4):411-21.

9. KANDOLIN R., LEHTONEN J., AIRAKSINEN J., VIHINEN T., MIETTINEN H., YLITALO K., et al. Cardiac sarcoidosis: epidemiology, characteristics, and outcome over 25 years in a nationwide study. Circulation. 2015;131(7):624-32.

10. NERY P.B., BEANLANDS R.S., NAIR G.M., GREEN M., YANG J., MCARDLE B.A., et al. Atrioventricular block as the initial manifestation of cardiac sarcoidosis in middle-aged adults. J Cardiovasc Electrophysiol. 2014;25(8):875-81.

11. FLEMING H.A. Cardiac sarcoidosis. Sarcoidosis. 1991;8(2):167-8. 
12. CHAPELON-ABRIC C., DE ZUTTERE D., DUHAUT P., VEYSSIER P., WECHSLER B., HUONG D.L., et al. Cardiac sarcoidosis: a retrospective study of 41 cases. Medicine. 2004;83(6):315-34.

13. VILES-GONZALEZ J.F., PASTORI L., FISCHER A., WISNIVESKY J.P., GOLDMAN M.G., MEHTA D. Supraventricular arrhythmias in patients with cardiac sarcoidosis; prevalence, predictors, and clinical implications. Chest. 2013;143(4):1085-90.

14. YATSYNOVICH Y., DITTOE N., PETROV M., MAROZ N. Cardiac Sarcoidosis: A Review of Contemporary Challenges in Diagnosis and Treatment. Am J Med Sci. 2018;355(2):113-25.

15. DOUGHAN A.R., WILLIAMS B.R. Cardiac sarcoidosis. Heart. 2006;92(2):282-8.

16. DUBREY S.W., BELL A., MITTAL T.K. Sarcoid heart disease. POstgrad Med J. 2007;83(984):618-23.

17. JOYCE E., KAMPERIDIS V., NINABER M.K., KATSANOS S., DEBONNAIRE P., SCHALIJ M.J., et al. Prevalence and Correlates of Early Right Ventricular Dysfunction in Sarcoidosis and Its Association with Outcome. J Am Soc Echocardiogr. 2016;29(9):871-8.

18. SEKHRI V., SANAL S., DELORENZO L.J., ARONOW W.S., MAGUIRE G.P. Cardiac sarcoidosis: a comprehensive review. Archives of medical science : AMS. 2011;7(4):546-54.

19. ISOBE M., TEZUKA D. Isolated cardiac sarcoidosis: clinical characteristics, diagnosis and treatment. Int J Cardiol. 2015;182:132-40.

20. MEHTA D., LUBITZ S.A., FRANKEL Z., WISNIVESKY J.P., EINSTEIN A.J., GOLDMAN M., et al. Cardiac Involvement in Patients with Sarcoidosis: Diagnostic and Prognostic Value of Outpatient Testing. Chest. 2008;133(6):1426-35.

21. SCHULLER J.L., OLSON M.D., ZIPSE M.M., SCHNEIDER P.M., ALEONG R.G., WIENBERGER H.D., et al. Electrocardiographic characteristics in patients with pulmonary sarcoidosis indicating cardiac involvement. J Cardiovasc Electrophysiol. 2011;22(11):1243-8.

22. HAMZEH N., STECKMAN D.A., SAUER W.H., JUDSON M.A. Pathophysiology and clinical management of cardiac sarcoidosis. Nat Rev Cardiol. 2015;12(5):278-88.

23. OTSUKA K., TERASAKI F., EISHI Y., SHIMOMURA H., OGURA Y., HORII T., et al. Cardiac Sarcoidosis Underlies Idiopathic Dilated Cardiomyopathy Importance of Mediastinal Lymphadenopathy in Differential Diagnosis. Circ J. 2007; 71(12):1937-41.

24. KIM J.S., JUDSON M.A., DONNINO R., GOLD M., COOPER L.T., JR., PRYSTOWSKY E.N., et al. Cardiac sarcoidosis. Am Heart J. 2009;157(1):9-21.

25. KOURANOS V., TZELEPIS G.E., RAPTI A., MAVROGENI S., AGGELI K., DOUSKOU M., et al. Complementary Role of CMR to Conventional Screening in the Diagnosis and Prognosis of Cardiac Sarcoidosis. JACC Cardiovasc Imaging. 2017;10(12):1437-47.

26. SHARMA S. Cardiac imaging in myocardial sarcoidosis and other cardiomyopathies. Current opinion in pulmonary medicine. 2009;15(5):507-12.

27. YOUSSEF G., LEUNG E., MYLONAS I., NERY P., WILLIAMS K., WISENBERG G., et al. The use of 18F-FDG PET in the diagnosis of cardiac sarcoidosis: a systematic review and metaanalysis including the Ontario experience. $\mathrm{J}$ Nucl Med. 2012;53(2):241-8

28. BENNETT M.K., GILOTRA N.A., HARRINGTON C., RAO S., DUNN J.M., FREITAG T.B., et al. Evaluation of the role of endomyocardial biopsy in 851 patients with unexplained heart failure from 2000-2009. Circ Heart Fail. 2013;6(4):676-84.

29. BIRNIE D.H., SAUER W.H., BOGUN F., COOPER J.M., CULVER D.A., DUVERNOY C.S., et al. HRS expert consensus statement on the diagnosis and management of arrhythmias associated with cardiac sarcoidosis. Heart Rhythm. 2014;11(7):1305-23.

30. YOSHINAGA K., MIYAGAWA M., KISO K., ISHIDA Y. Japanese Guidelines for Cardiac Sarcoidosis. Ann Nucl Cardiol. 2017;3(1):121-4.

31. LIMPER A.H., KNOX K.S., SAROSI G.A., AMPEL N.M., BENNETT J.E., CATANZARO A., et al. An official American Thoracic Society statement: Treatment of fungal infections in adult pulmonary and critical care patients. Am J Respir Crit Care Med. 2011;183(1):96-128.

32. SADEK M.M., YUNG D., BIRNIE D.H., BEANLANDS R.S., NERY P.B. Corticosteroid Therapy for Cardiac Sarcoidosis: A Systematic Review. Can J Cardiol. 2013;29(9):1034-41.

33. BEEGLE S.H., BARBA K., GOBUNSUY R., JUDSON M.A. Current and emerging pharmacological treatments for sarcoidosis: a review. Drug Des Devel Ther. 2013;7:325-38.

34. EPSTEIN A.E., DIMARCO J.P., ELLENBOGEN K.A., ESTES N.A.M., FREEDMAN R.A., GETTES L.S., et al. ACC/AHA/HRS 2008 Guidelines for Device-Based Therapy of Cardiac Rhythm Abnormalities: A Report of the American College of Cardiology/American Heart Association Task Force on Practice Guidelines (Writing Committee to Revise the ACC/AHA/NASPE 2002 Guideline Update for Implantation of Cardiac Pacemakers and Antiarrhythmia Devices) Developed in Collaboration With the American Association for Thoracic Surgery and Society of Thoracic Surgeons. J Am Coll Cardiol. 2008;51(21):e1-e62.

35. ROSENTHAL D.G., BRAVO P.E., PATTON K.K., GOLDBERGER Z.D. Management of Arrhythmias in Cardiac Sarcoidosis. Clin Cardiol. 2015;38(10):635-40.

Received September 11, 2018 